\title{
Prenatal Development of Yankasa Sheep (Ovis aries) Kidney: A Histomorphometric Study
}

\author{
A Bello ${ }^{1 *}$, DI Dabai ${ }^{1}$, MA Umaru ${ }^{2}$, SA Shehu ${ }^{1}$ and MI Jimoh ${ }^{1}$ \\ ${ }^{1}$ Department of Veterinary Anatomy, Usmanu Danfodiyo University, Sokoto, Nigeria \\ ${ }^{2}$ Department of Theriogenology and Animal production, Usmanu Danfodiyo University, Sokoto, Nigeria \\ *Corresponding author: Dr. A. Bello: Department of Veterinary Anatomy, Usmanu Danfodiyo University, Sokoto, Nigeria, Tel: +234(0)8039687589; E-mail: \\ abccrcfge28@gmail.com
}

Rec date: Dec 15, 2015; Acc date: May 19, 2016; Pub date: May 26, 2016

Copyright: @ 2016 Bello A, et al. This is an open-access article distributed under the terms of the Creative Commons Attribution License, which permits unrestricted use, distribution, and reproduction in any medium, provided the original author and source are credited.

\begin{abstract}
A Histomorphometric study was conducted on the kidney of seventeen (17) fetuses of the Yankasa sheep (Ovis aries) collected from the Sokoto metropolitan abattoir, over a period of one month at different gestational ages. The approximate age of the fetuses was estimated from the crown vertebral rump length (CVRL) and samples were categorised into first, second and third trimester. Out of the seventeen (17) fetuses at different gestational age used for the study, $7(48 \%)$ were females while $10(52 \%)$ were males. $6(35 \%)$ fetuses belong to first trimester, $5(30 \%)$ belong to second trimester and $6(35 \%)$ belong to third trimesters of pregnancy respectively. The mean crown vertebrate-rump length (CVRL) ranged from $12.47 \pm 1.80 \mathrm{~cm}$ at first trimester to $33.79 \pm 1.52 \mathrm{~cm}$ at third trimester. Histological observation shows that the kidney appeared to have two zones via cortex and medulla right from first to third trimester. The development of renal tissues were found to be in succession, from the stage of mesenchyme cells, developing glomerulus and finally to fully developed glomerulus with advancement of gestational age among the three groups. The duct system also followed the same trend of development from immature to matured duct system. The cortex of the first trimester kidney was found to have numerous mesenchymal cells and connective tissues with few developing glomerulus. At second trimester few fully developed glomerulus were found, moderate number of mesenchyme cells and immature developing duct system. Numerous developed glomerulus and matured duct system with moderate developing glomerulus and connective tissue were seen at third trimester. The medulla at first trimester shows only various types of connective tissue (collagen, reticular and elastic) fibers and mesenchyme cells. At second trimester the medulla was found to have numerous developing collecting ducts, few developed collecting ducts and few mesenchyme cells. Developed collecting ducts were predominant in the medulla at third trimester with few mesenchyme cells. The histological differentiation of the Yankasa sheep kidney is similar to that of ovine, bovine, equine, Llama, and guanaco but differs from that of the feline, canine and porcine. Meanwhile, considering the histological features observed in the study, the Yankasa sheep kidney may become fully matured and functional at post-natal age.
\end{abstract}

Keywords: Histological; Kidney; Prenatal development; Yankasa sheep

\section{Introduction}

Yankasa sheeps are member of a class of animals called ruminants. These animals ruminant (chew their cud). Unlike other animals, they have four-compartment stomachs especially designed to digest roughage (food high in fiber) such as grass, hay and silage [1]. Anatomically, the ruminant stomach comprises of the rumen, the honey-combed reticulum, the leaf like Omasum and the abomasum or true stomach [2]. The size relationship of four chambers changes as the animal grows up [1]. Small ruminants, (sheep and goats) are increasingly becoming a major source of animal protein in Nigeria, contributing over 30 percent to total meat consumption in the country [3].

Yankasa sheeps are widely distributed throughout the world. The total world cattle population is estimated to be more than 1.4 billion head, with about 35 percent in Africa, 23 percent in Asia, 17 percent in South America, 12 percent in North and Central America, 10 percent in Europe, and 3 percent in Oceania [4].
Histomorphological studies of prenatal development of various organs in yankasa sheeps spp has been carried out extensively [1,5-11] but little of such studies have been conducted on the developmental changes of the yankasa sheeps fetal kidney in this area. However, there is thus, paucity of information on the prenatal development of yankasa sheeps kidney [12]; hence the present study was undertaken to bridge the gap of the existing information.

\section{Materials and Method}

The study was carried out on 17 fetuses of the yankasa sheeps collected from the metropolitan abattoir, Sokoto, Nigeria, at different gestational ages. The collected fetuses were then taken to the Veterinary Anatomy laboratory of Usmanu Danfodiyo University, where the weight and age of the fetus were determined. The fetal body weight was measured using electrical (digital) weighing balance for the smaller fetuses and compression spring balance (AT-1422), size C-1, sensitivity of $20 \mathrm{~kg} \times 50 \mathrm{~g}$ in Kilogram for the bigger fetuses. The approximate age of the fetuses was estimated using the following formula as adopted by Gall, et al 1994 [13].

$$
\mathrm{G} . \mathrm{A}=(\mathrm{CVRL}+30.15) / 2.74
$$


Citation: Bello A, Dabai DI, Umaru MA, Shehu SA, Jimoh MI (2016) Prenatal Development of Yankasa Sheep (Ovis aries) Kidney: A

Page 2 of 5

Where GA (Gestational Age) is in days, CVRL (Crown Vertebral rump Length) is in centimeter, and measured as a curved line along the vertebral column from the point of the anterior frontal bone following the vertebral curvature to the base of the tail [2]. Based on this, the following guide fetus were place in to various stages of gestational ages (trimester):

First Trimester $=1-51$ days; Second Trimester $=52-102$ days; Third trimester $=103-153$ days

The kidneys of each fetus were collected by placing the fetus on dorsal recumbency and a mid-ventral skin incision was made via the abdomino-pelvic region down to the thoracic region. The abdominothoracic content was removed entirely to gain access to the position of the kidneys.

$1 \mathrm{~cm}^{2}$ thick of sample from each group was collected and fixed in $10 \%$ formalin solution. After fixation was achieved, the tissue sample was processed for paraffin blocks preparation. The sections of $5 \mu \mathrm{m}$ were subjected to haematoxylin and eosin for routine morphology [14]. The standard sections were examined under light microscope and micrographs taken using digitalized Sony camera with 12.1 mega pixels.

\section{Result and Discussion}

Out of the twenty five (17) fetuses at different gestational age used for the study, seven (48\%) were females while ten (52\%) were males. $6(35 \%)$ fetuses belong to first trimester, $5(30 \%)$ belong to second trimester and 6(35\%) belong to third trimesters of pregnancy respectively. The mean crown vertebrate-rump length (CVRL) ranged from $12.47 \pm 1.80 \mathrm{~cm}$ at first trimester to $33.79 \pm 1.52 \mathrm{~cm}$ at third trimester as shown in Table 1.

From the study, the result shows that with the advancement of gestation the morphometric data were increasing progressively across the various stages of development as shown in Table 2. This is in accordance with the finding of Hena et al., 2012, on pigeon, Bello et al., 2013 on cattle kidney and Bello et al., 2012 on camel digestive tract $[2,3,15]$.

\begin{tabular}{|c|c|c|c|c|}
\hline \multirow{2}{*}{ Trimester } & \multirow{2}{*}{$\begin{array}{l}\text { Mean CRVL (cm } \\
\pm \text { SEM) }\end{array}$} & \multicolumn{2}{|l|}{ SEX } & \multirow{2}{*}{$\begin{array}{l}\text { Mean Weight } \\
(\mathrm{g} \pm \mathrm{SEM})\end{array}$} \\
\hline & & Male & Female & \\
\hline $1^{\text {st }}$ & $12.47 \pm 1.80$ & 4 & 2 & $126.15 \pm 4.74$ \\
\hline $2^{\text {nd }}$ & $22.16 \pm 1.17$ & 2 & 3 & $452.12 \pm 4.25$ \\
\hline \multirow[t]{2}{*}{$3^{\text {rd }}$} & $33.79 \pm 1.52$ & 4 & 2 & $1801.39 \pm 7.58$ \\
\hline & Total & 10 & 7 & \\
\hline
\end{tabular}

Table 1: The mean CRVL, mean weight and sex of the yankasa sheeps fetuses at various trimesters of age.

\begin{tabular}{|c|c|c|c|}
\hline Parameters & $\begin{array}{l}\text { 1st } \\
\text { Trimester }\end{array}$ & $\begin{array}{l}\text { 2nd } \\
\text { Trimester }\end{array}$ & $\begin{array}{l}\text { 3rd } \\
\text { Trimester }\end{array}$ \\
\hline Sample size & 6 & 5 & 6 \\
\hline \multicolumn{4}{|c|}{ Mean Weight (g \pm SEM) } \\
\hline Right Kidney & $0.68 \pm 0.19$ & $2.00 \pm 0.17$ & $3.74 \pm 0.28$ \\
\hline
\end{tabular}

\begin{tabular}{|l|l|l|l|}
\hline & $0.68 \pm 0.19$ & $2.44 \pm 0.28$ & $3.88 \pm 0.30$ \\
\hline Left kidney & $1.27 \pm 0.19$ & $2.36 \pm 0.11$ & $2.86 \pm 0.04$ \\
\hline Right kidney & $1.44 \pm 0.13$ & $2.48 \pm 0.05$ & $3.88 \pm 0.30$ \\
\hline Left kidney & $0.82 \pm 0.11$ & $1.44 \pm 0.10$ & $1.66 \pm 0.08$ \\
\hline Mean Width (cm \pm SEM) & $0.83 \pm 0.12$ & $1.48 \pm 0.08$ & $1.68 \pm 0.08$ \\
\hline Right kidney & $0.82 \pm 0.29$ & $2.02 \pm 0.17$ & $3.18 \pm 0.31$ \\
\hline Left kidney & $0.82 \pm 0.29$ & $2.50 \pm 0.21$ & $3.20 \pm 0.36$ \\
\hline Mean Volume (cm ${ }^{3} \pm$ SEM) & \multicolumn{5}{|l|}{} \\
\hline Right kidney &
\end{tabular}

Table 2: The Mean \pm SEM of biometrical parameters of right and left yankasa sheeps kidneys in relation to stages of development

Histological observation shows that the kidney appeared to have two zones via cortex and medulla right from 1st trimester as shown in Figures 1-4. The development of renal tissues were found to be in succession, from the stage of mesenchyme cells, developing glomerulus and finally to fully developed glomerulus with advancement of gestational age among the three groups as shown in Figures 1-8. The duct system also followed the same trend of development from immature to matured duct system.

The cortex of the first trimester kidney was found to have numerous mesenchymal cells and connective tissues with few developing glomerulus (Figure 1). At second trimester few fully developed glomerulus were found, moderate number of mesenchyme cells and immature developing duct system (Figure 2). Numerous developed glomerulus and matured duct system with moderate developing glomerulus and connective tissue were seen at third trimester (Figure 3). This is in agreement with Onarlioglu, et al. [16] that observed no developed glomeruli in the kidneys where dense mesenchymal tissue take place in early stage of development in rat foetus.

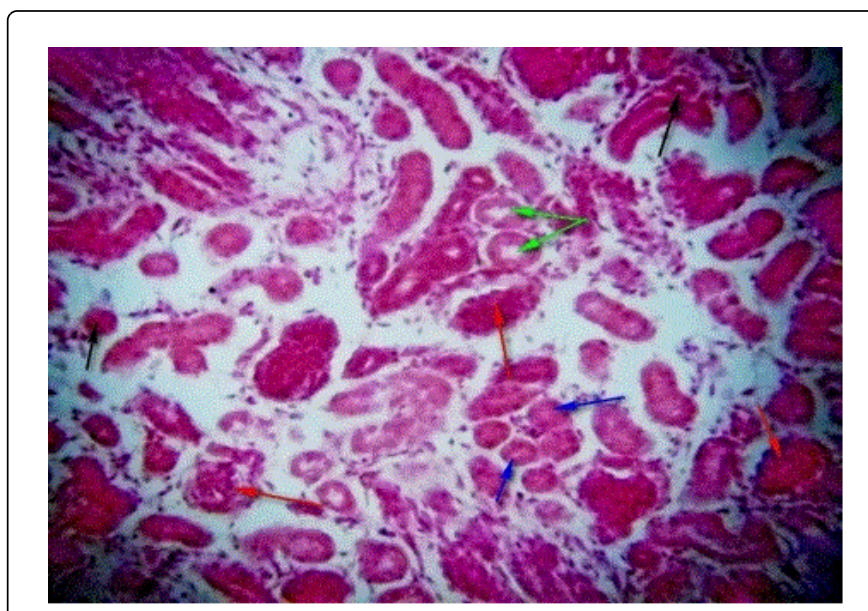

Figure 1: Photomicrograph of Yankasa sheep kidney (cortex) at $1^{\text {st }}$ Trimester showing premature glomerulus (Red arrow) with developing blood vessels (Black arrow) and prominent mesenchyme cells H\&E X200. 
Citation: Bello A, Dabai DI, Umaru MA, Shehu SA, Jimoh MI (2016) Prenatal Development of Yankasa Sheep (Ovis aries) Kidney: A Histomorphometric Study. J Kidney 2: 126. doi:10.4172/2472-1220.1000126

Page 3 of 5

The population of mesenchyme cells reduced in the second trimester, together with few fully developed glomerulus and immature developing duct system (Figure 2). There was slight coiling of the duct system at the cortex of the kidney (Figures 2 and 3). This is in line with that observed by El-Salmi and Amri [17] on Sudanese sheep.

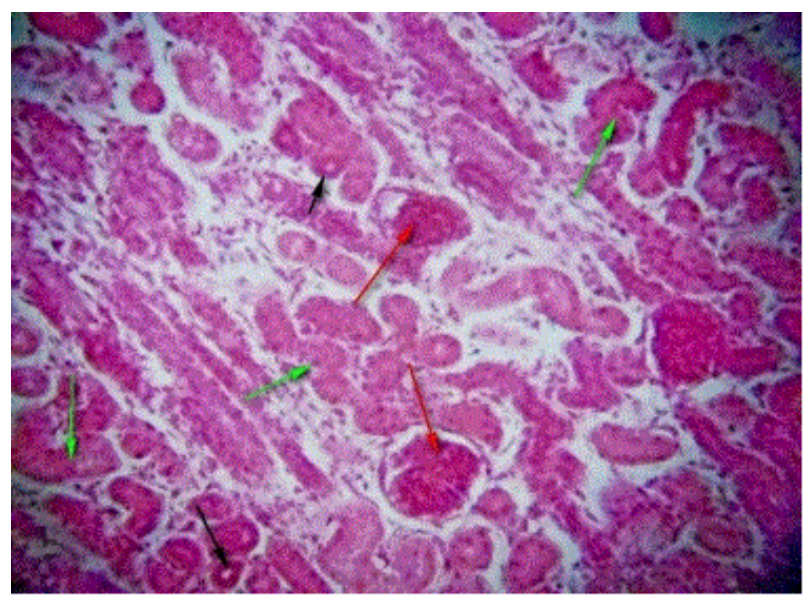

Figure 2: Photomicrograph of Yankasa sheep kidney (cortex) at $2^{\text {nd }}$ Trimester showing premature and mature glomerulus (Red arrow), differentiated connective tissues (Red arrow) with prominent blood vessels (Black arrow) and proliferative collecting ducts H\&E X200.

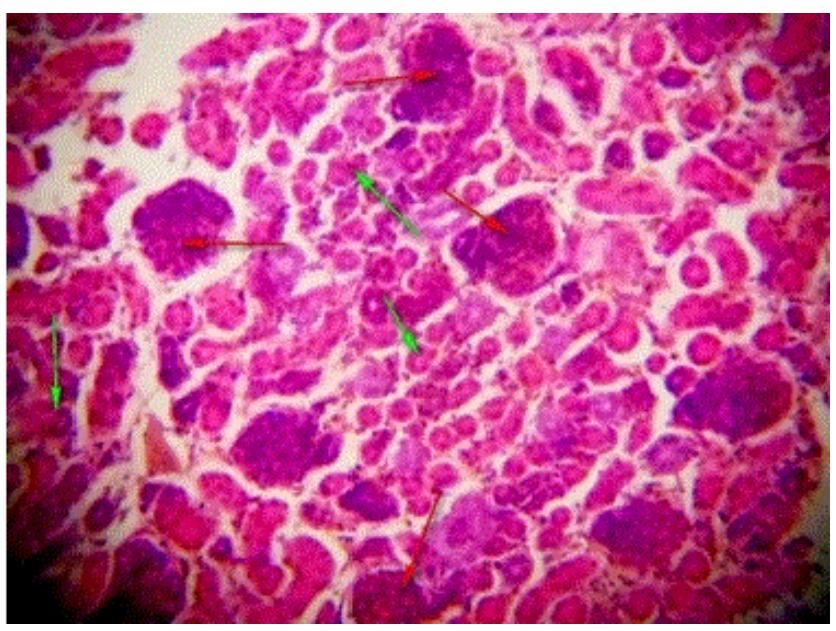

Figure 3: Photomicrograph of Yankasa sheep kidney (cortex) at 3rd Trimester showing mature glomerulus (Red arrow), differentiated connective tissues with numerous blood vessels (Green arrow) and mesenchyme cells H\&E X200.

The glomerulus in the cortex of the first trimester kidney was found to have undifferentiaed juxtaglomerula complex cells and connective tissues with few developing glomerulus (Figure 5). At second trimester few fully developed glomerulus were found with differentiated juxtaglomerula complex cells and moderate number of mesenchyme cells and immature developing duct system (Figure 6).

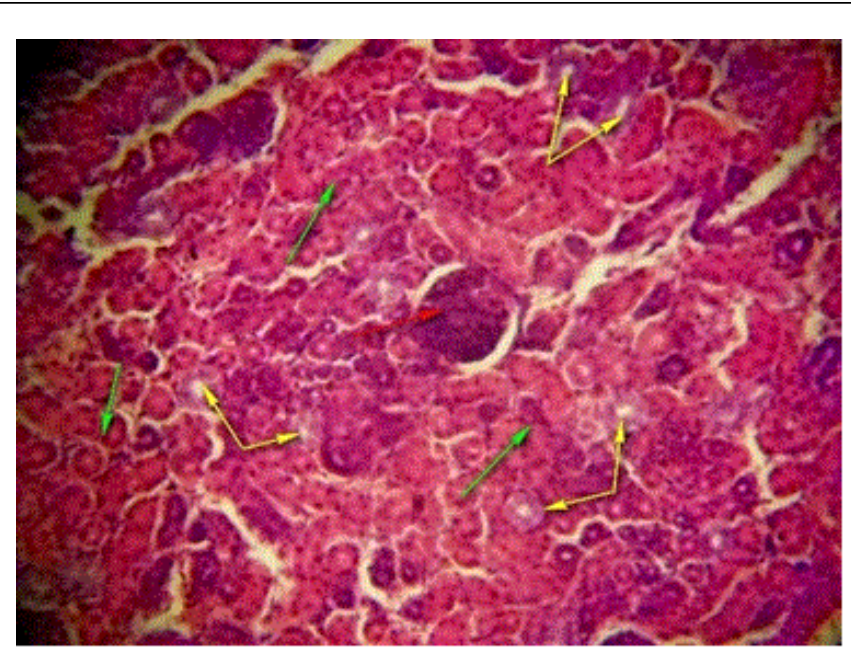

Figure 4: Photomicrograph of Yankasa sheep kidney (cortex) at 3rd Trimester showing mature glomerulus (Red arrow), with welldeveloped connective tissues and blood vessels (Yellow arrow) and mesenchyme cells H\&E X200.

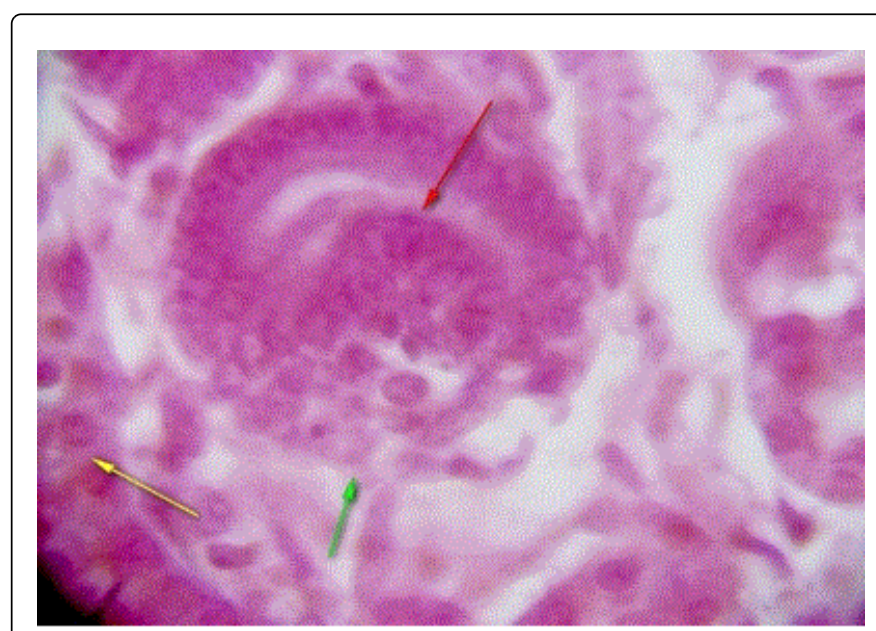

Figure 5: Photomicrograph of Yankasa sheep kidney (cortex) at $1^{\text {st }}$ Trimester showing premature glomerulus (Red arrow) undifferentiated juxtaglomerula complex (Green arrow) and mesenchyme cells (yellow arrow) H\&E X400.

Numerous developed glomerulus and matured duct system with moderate developing glomerulus and connective tissue were seen at third trimester with clear differentiated juxtaglomerula complex cells (Figures 7 and 8). This is in agreement with Onarlioglu, et al. (1997) that observed no developed juxtaglomerula complex cells in the glomeruli in the kidneys where dense mesenchymal tissue take place in early stage of development in rat foetus.

The appearance and differentiation of the juxtaglomerula complex cells and the population of mesenchyme cells reduced in the second trimester, together with few fully developed glomerulus and immature developing duct system (Figure 6 and 7).

This is in line with that observed by El-Salmi and Amri (2012) on Sudanese sheep and Franco, et al. (2004) on Llama [17,18]. 
Citation: Bello A, Dabai DI, Umaru MA, Shehu SA, Jimoh MI (2016) Prenatal Development of Yankasa Sheep (Ovis aries) Kidney: A Histomorphometric Study. J Kidney 2: 126. doi:10.4172/2472-1220.1000126

Page 4 of 5

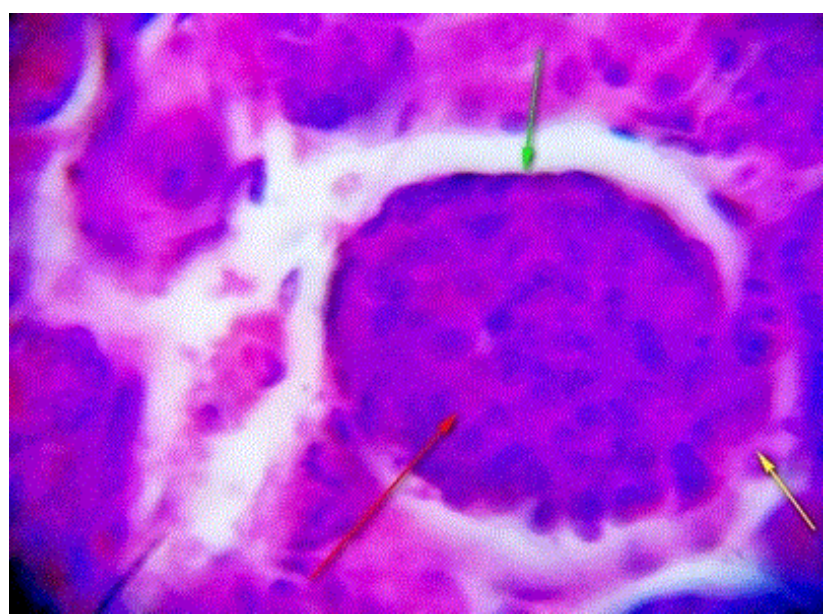

Figure 6: Photomicrograph of Yankasa sheep kidney (cortex) at $2^{\text {nd }}$ Trimester showing mature glomerulus (Red arrow), with differentiated epithelium of the bowman's capsule (Green arrow), differentiated developing juxta glomerula complex (yellow arrow) and mesenchyme cells and mesenchyme cells H\&E X400.

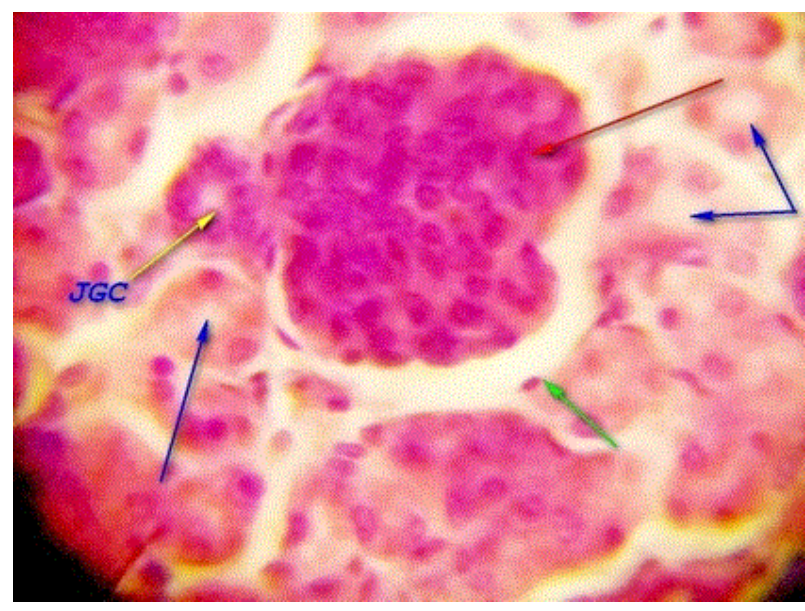

Figure 7: Photomicrograph of Yankasa sheep kidney (cortex) at 3rd Trimester showing mature glomerulus (Red arrow), with differentiated epithelium of the bowman's capsule (Green arrow), differentiated developing juxta glomerula complex (yellow arrow) and mesenchyme cells H\&E X400.

The medulla at first trimester shows only various types of connective tissue (collagen, reticular and elastic) fibers and mesenchyme cells (Figure 9).

At second trimester the medulla was found to have numerous developing collecting ducts, few developed collecting ducts and few mesenchyme cells (Figure 10).

Developed collecting ducts were predominant in the medulla at third trimester with few mesenchyme cells (Figure 11). This is also in line with that observed by Franco, et al. (2004) on Llama and El-Salmi and Amri (2012) on Sudanese sheep.

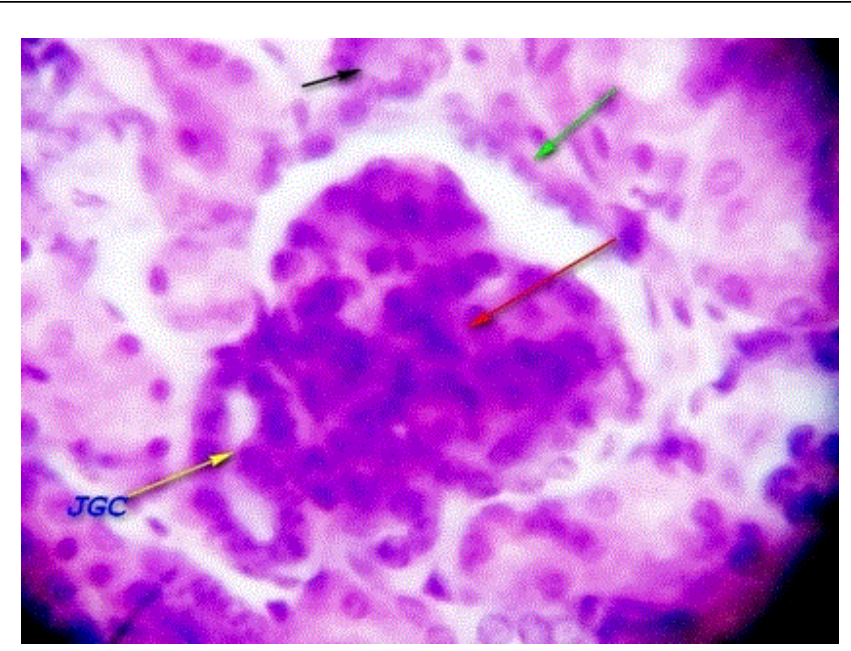

Figure 8: Photomicrograph of Yankasa sheep kidney (cortex) at $3^{\text {rd }}$ Trimester showing mature glomerulus (Red arrow), with differentiated epithelium of the Bowman's capsule (Green arrow), differentiated developed juxta glomerula complex (yellow arrow) and mesenchyme cells H\&E X400.

At third trimester the kidneys showed predominant developed collecting ducts and few mesenchyme cells, which showed the kidneys, were still developing.

This trend of growth was in accordance with the findings of Bello, et al. (2012), who reported that variable growth and structural diversities at different stages of development of an organ is a normal phenomenon for accommodating and molding of the organ.

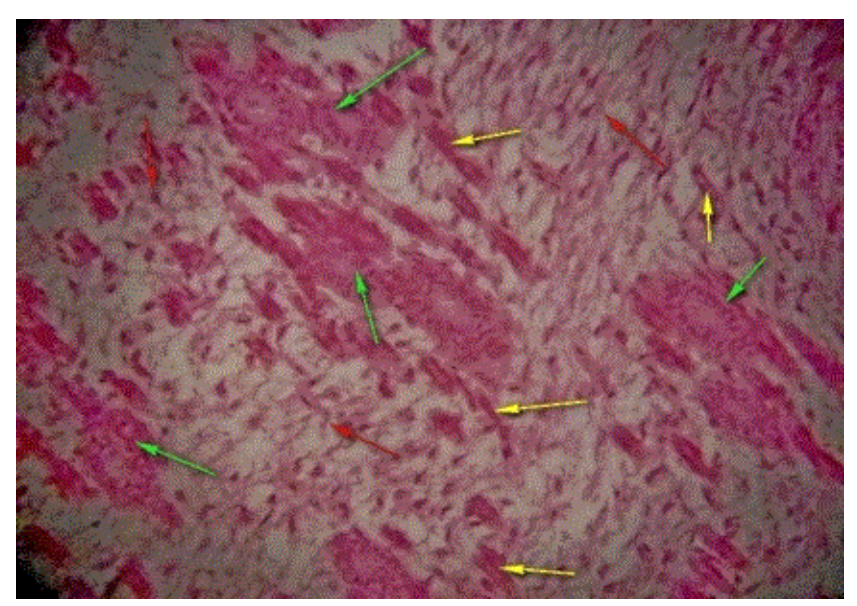

Figure 9: Photomicrograph of Yankasa sheep kidney (medulla) at $1^{\text {st }}$ Trimester showing premature connective tissues; collagen (green arrow), reticular (Red arrow), elastic (Yellow arrow) and mesenchyme cells (yellow arrows) with no evidence of blood vessels H\&E X200. 
Citation: Bello A, Dabai DI, Umaru MA, Shehu SA, Jimoh MI (2016) Prenatal Development of Yankasa Sheep (Ovis aries) Kidney: A Histomorphometric Study. J Kidney 2: 126. doi:10.4172/2472-1220.1000126

Page 5 of 5

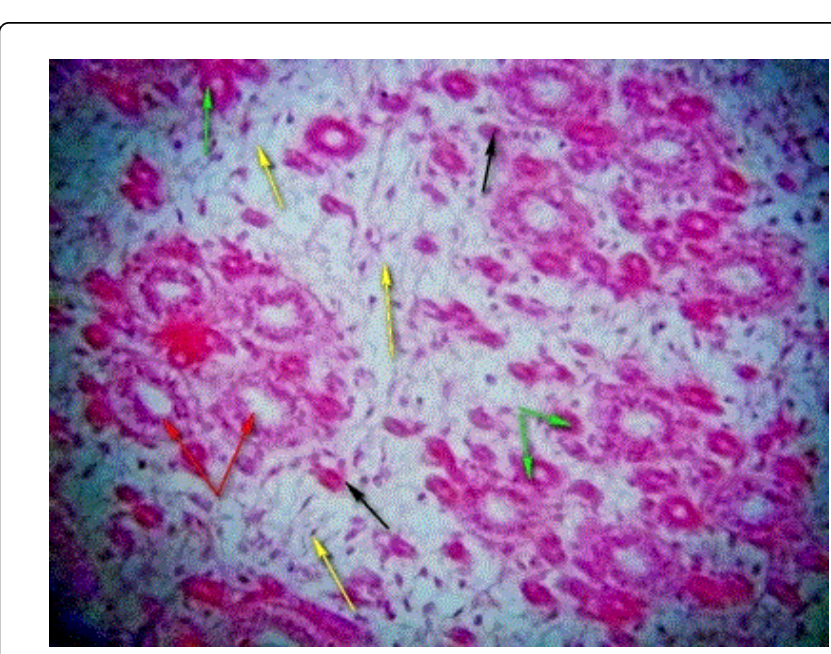

Figure 10: Photomicrograph of Yankasa sheep kidney (medulla) at 2nd Trimester showing premature connective tissues; collagen with evidence of blood vessels (green arrow), reticular (Yellow arrow), elastic (Black arrow) developing collecting ducts (Cd),developed collecting ducts (C) and mesenchyme cells H\&E X200.

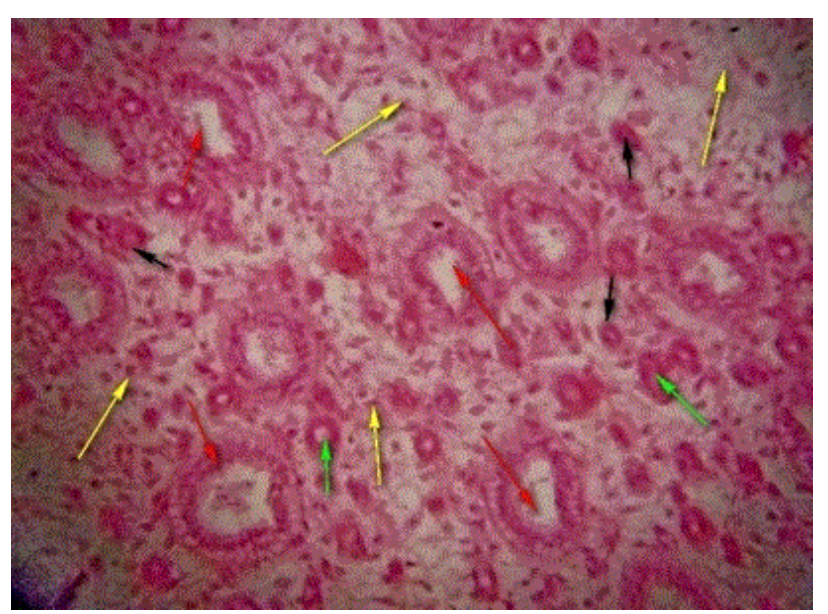

Figure 11: Photomicrograph of Yankasa sheep kidney (medulla) at 3rd Trimester showing matured connective tissues; collagen with numerous blood vessels (green arrow), reticular (Yellow arrow), elastic (Black arrow), developed collecting ducts (C) and mesenchyme cells H\&E X200.

\section{Conclusion}

In conclusion, the histological differentiation of the Yankasa sheep kidney is similar to that of Ovine, Bovine, Equine, Llama, and Guanaco but differs from that of the feline, canine and porcine.
Meanwhile, considering the histological features observed in the study, the Bovine kidney may become fully matured and functional at postnatal age.

\section{References}

1. Asari M, Oshige H, Wakui S, Fukaya K, Kano Y (1985) Histological development of bovine abomasum. Anat Anz 159: 1-11.

2. Bello A, Onyeanusi BI, Sonfada ML, Adeyanju JB, Umaru MA (2012) A biometric study of the digestive tract of one-humped camel (camelus dromedarius) fetuses. Scientific Journal of Zoology 1: 11-16.

3. Bello A, Sonfada ML, Umar AA, Umaru MA, Shehu SA, et al. (2013). Age estimation of camel in Nigeria using rostral dentition: Scientific Journal of Animal Science 2: 9-14.

4. Abd-Elmaksoud A (2005) Morphological, glycohistochemical and immunohistochemical studies on the embryonic and adult bovine testis. Ph.D. Thesis, Ludwig-Maximilians-Universitat.

5. Wilson RT, Araya A, Melaku A (1990) The One-Humped Camel: An Analytical and Annotated Bibliography 1980-1989. UNSO Technical Publication. Bartridge Partners, Umberleigh, North Devon EX379AS U.K.

6. Reece WO (1997) Physiology of domestic animals. Williams and Wilkins 11:334.

7. Bustinza AV (1979) South American Camelids. In: IFS Symposium Camels. Sudan: 73-108.

8. Franco AJ, Masot AJ, Aguado MC, Gómez L, Redondo E (2004) Morphometric and immunohistochemical study of the rumen of red deer during prenatal development. J Anat 204: 501-513.

9. Belknap EB (1994) Medical problems of llamas. In: The Vet. Cl. of North American food and Animal Practice, Update on Llama Medicine. Johnson, L. W. (Editor). Philadelphia, W. B. Saunders Co.

10. Watrous BJ, Pearson EG, Smith BB, Snyder SP, Blythe LL, et al. (1995) Megaesophagus in 15 llamas: a retrospective study (1985-1993). J Vet Intern Med 9: 92-99.

11. Jamdar MN, Ema AN (1982) The submucosal glands and the orientation of the musculature in the oesophagus of the camel. J Anat 135: 165-171.

12. Luciano L, Voss-Wermbter G, Behnke M, von Engelhardt W, Reale E (1979) [The structure of the gastric mucosa of the llamas (Lama guanocoe and Lama lamae). I. Forestomach]. Gegenbaurs Morphol Jahrb 125: 519-549.

13. Gall CF, Stier CH, Frahm K (1994) Age estimation of yankasa sheep fetus. Small Ruminant Res 14: 91-94

14. Luiz CJ, Jose C (2005) Basic Histology Text and Atlas 11th ed. McGrawHill.

15. Hena SA, Sonfada ML, Onyeanusi BI, Kene ROC, Bello A (2012) Radiographic studies of developing calvaria at prenatal stages in onehumped camel. Sokoto Journal of Veterinary Sciences. 10: 13-16.

16. Onarlioglu B, Gursoy E, Kaloglu C (1997) Renal Morphogenesis of rat fetus. Turk J Anim Sci 21: 493-496.

17. El-Salmi, Amri (2012) Genetic Diversity and relationships of Indigenous Saudi Arabia Camel (Camelus dromedarius) Populations. In: The proceedings of the Proceedings of the 3rd Conference of the International Society of Camelid Research and Development: 40.

18. Franco AJ, Masot AJ, Aguado MC, Gómez L, Redondo E (2004) Morphometric and immunohistochemical study of the rumen of red deer during prenatal development. J Anat 204: 501-513. 